\title{
A Trip Home, and Other Notes
}

STUART FRANCIS, Torch River

After a very pleasant and interesting meeting of our Natural History Society, we left the following Sunday morning, after spending a few minutes enjoying the beauties of Wascana Park. We headed east, and the first item of interest was to have a car pass us on the Trans-Canada Highway with an Alaska license plate. Then as we drove through Fort Qu'Appelle we were amused to note a professional sign which read as follows: "W. Stiff, Undertaker," which appeared to be very appropriate.

Nearing the country around Archerwell we noted many flocks of wild ducks, about 75 Brewer Blackbirds, a single Blue Jay and from 15 to 20 Bohemian Waxwings. I am sorry to say one bird was very conspicuous by its absence, and that bird was the Sharp-tailed Grouse-we did not see a single one in nearly 600 miles travelled on the round trip. I, for one, believe it is time to impose a closed hunting season on these birds until they again become more numerous, or they will soon be as scarce as the Pinnated Grouse. One Ruffed Grouse was seen between Archerwell and Wadena.

On October 30 th the main migration of Whistling Swans was on and the weather became colder with some snow. One of the boys went to the storehouse for a pair of rubbers only to find both of them stuffed full of toadstools by the Red Squirrels.

On November 1st we made the trip of 60 miles to Fishing Lakes, to get our boat beached for the winter. On the way in we saw the tracks of four Timber Wolves, one very large one. Most other game appeared scarce in this area. We saw a lone gull on the lake, probably a Ringbilled Gull. While returning we saw several deer.

On November 2 nd we had snow to a depth of $4 \frac{1}{2}$ inches, with blizzard conditions. On November 4th, the early morning temperature was 8 degrees above zero, but rose sharply to 40 above by noon. Migrating birds noted on this date were as follows: a small flock of Juncos, 2 Horned

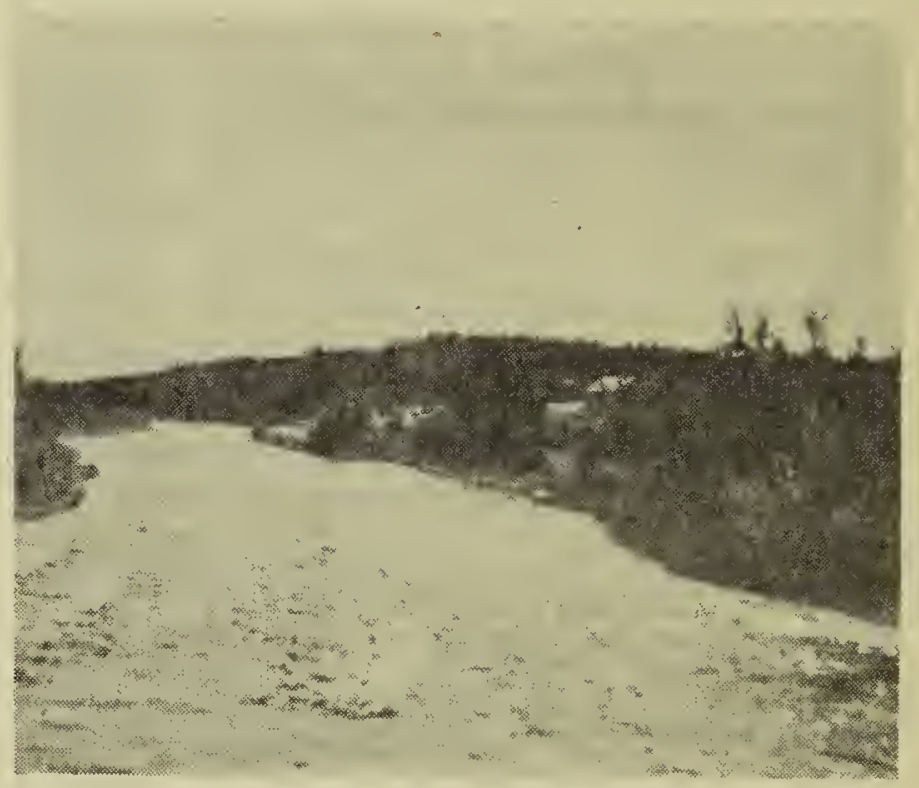

\section{The Torch River}

Larks, a Brewer Blackbird and a Marsh Hawk. On November 5th, a flock of about 35 Bohemian Waxwings were feeding on the Siberian Crabapples, honeysuckles, etc.

Up to the time of writing this report, all migratory birds except two or three Juncos appear to have left for the south.

On this day of November 11, Armistice Day, a day which is supposed to be dedicated to the silencing of the guns of war and the ending of the bloodshed and misery which accompanies war, the guns of the big game hunters were cracking loud and furious. I am not against hunting, in fact I enjoy it, if done in a sportsmanlike manner, but I do think that hunting on Armistice Day is unnecessary, and should be put in the same status as Sundays.

Mr. P. W. Grant, who wrote "The Archeologist's Stick" sends best wishes to "The Blue Jay" from the Manitoba archeological section. He has been collecting artifacts for some years and has been out with MacNeish of Ottawa, Wettlaufer (at times employed by Saskatchewan), the Stokes, Mrs. Helyar and others. The frequent mention in the article of beach and rock comes from searching in the lowered forebay of the Pointe du Bois power plant, where he has assisted in collecting 4,900 artifacts. 